\title{
Development Model for Environment-Based Learning to Improve Junior High School Students' Geographical Skills
}

\section{Nur HAMID 1}

Universitas Islam Negeri Walisongo Semarang, INDONESIA

Dewi Liesnoor SETYOWATI ${ }^{3}$

Universitas Negeri Semarang, INDONESIA

Muh. Arif ROYYANI ${ }^{5}$

Universitas Islam Negeri Walisongo Semarang, INDONESIA
Gillian ROEHRIG ${ }^{2}$

University of Minnesota, UNITED STATES

Huriah RACHMAH ${ }^{4}$

Universitas Islam Bandung, INDONESIA

Hanifah MAHAT6

Universiti Pendidikan Sultan Idris, MALAYSIA

${ }^{1}$ Corresponding author: Lecturer. Department of Islamic Community Development, Universitas Islam Negeri Walisongo Semarang, Indonesia elnur.hamid [at] walisongo.ac.id. ORCID: 0000-0002-7447-5872

2 Prof. Dr., Department of Curriculum and Instruction, University of Minnesota, Minnesota, United States, roehr013 [at] umn.edu. ORCID: 0000-0002-6943-7820

3 Prof. Dr., Department of Geography, Universitas Negeri Semarang, Indonesia liesnoor2015 [at] mail.unnes.ac.id. 0RCID: 0000-0002-6191-6026

${ }^{4}$ Lecturer. Department of Early Childhood Education, Universitas Islam Bandung, Indonesia huriahrachmah [at] unisba.ac.id. ORCID: 0000-0003-1375-2001

5 Lecturer., Department of Astronomy, Universitas Islam Negeri Walisongo Semarang, Indonesia . arif.royyan [at] walisongo.ac.id. ORCID: 0000-0002-0225-0420

${ }^{6}$ Assoc. Prof., Department of Geography and Environment, Universiti Pendidikan Sultan Idris, Perak, Malaysia. Hanifah.mahat [at] fsk.upsi.edu.my,. ORCID: 0000-0003-0756-6907

\section{Abstract}

In this study, an obstacle unlikely faced by teacher is the lack of innovation in the learning model employed. The teachers are still being the center of learning resources so that they are made to correct the perception by creating a learning model that students prefer. This study aims to provide a new design in environment-based-learning (EBL) to improve geographical skills and to encourage students to think critically, innovatively and to come up with solutions. This research was development study of environment-based-learning in geography teaching. Learning media used covered syllabus, lesson plans, student modules and EBL teaching materials. Samples consisted of 32 students aged 13 14 years who were purposively selected. Data collection techniques were a compilation of observation, interviews, questionnaires documentation, and test. Data were analyzed from the syllabus, study plan, and student module validation along with instructional media, teacher and student response questionnaire, teacher and student interviews, student observation sheets, and students' learning outcomes. EBL model design consisted of 5 steps, encountering the problem, problem analysis, discovery and reporting, presentation, and review and evaluation. The students' learning outcome that asses by a test base on geographical skill indicator revealed that students' geographical skills increase. The indication are the students able on thinking critically about changes taken place in their environment, so they could present environmentally friendly measures. Besides, students preferred the new design of EBL as they were welcomed to think in a critical, innovative, and solvable way of solving problems in their environment to improve their geographical skills. Those provided students a belief in loving geography education from an early age.

\section{Keywords}

Environment-Based-Learning, Loving the Geography Education, Geographical Skills 
Geography education is an integrated discipline across both the social sciences and physical sciences, which allows students to apply geography knowledge and skills to real world situations. Geography is the study of the physical features of the earth and how human activity influences the physical environment. The study of geography is intended to address problems that exist in human life and the environment (Sugiyanto et al., 2017; Wasino, 2020), such as the distribution and use of resources and land use. Thus, geography education helps society to develop social resilience and build the ability of students to act wisely, and responsibly in dealing with social, economic, and ecological problems (Sugandi, 2015).

Geography education aims to develop global citizens and an understanding of the surface of the earth, natural phenomena, the environment, and natural resources, as well as application of this learning to daily life (Dukomalamo \& Amelia, 2019; Hakim \& Riyani, 2015; Kusumawat, 2015; Mu'aini, 2016). The main purpose of geography education is to help learners develop relevant skills to make important decisions that affect their relationship with humans and with the surrounding environment (Winch \& Gingell, 2008).

Given the importance of increasing students' geographical thinking skills, teachers need to learn and implement appropriate learning methods. The main components of geography education that teachers must know are: social science knowledge, knowledge of the natural environment, the skills needed to implement this knowledge in pedagogically meaningful ways, and an understanding of the value of social citizen participation in society (Rochmawati \& Siradjuddin, 2018; Syaichudin et al., 2016; Tamba et al., 2018; Wau, 2017). Geography learning relies on the selection of appropriate learning models and strategies by the teacher (Mu'aini, 2016; Mustofani \& Hartinah, 2019), as the selection of quality learning models affects the success of student learning (Hamid, et al., 2020; Zarvianti \& Sahida, 2020).

One appropriate method for improving students' geography skills is the environment-based learning method. Students are introduced geographical content related to recognizing the kinds of natural resources around them. The goal is for students to think critically and innovatively to describe the phenomena and natural resources in their surroundings. As reported by Pasongli et al (2020), problembased learning about the environment can increase students' knowledge in geographic thinking. In addition, this approach to learning provides motivation to students (Faiz \& Avci, 2020) and the development of specific geography skills and attitudes, such as spatial-based learning. As this approach promotes environmentally thinking in a spatial context (Seyhan, 2019).

Geography learning situated in the students' immediate environment makes learning fun. Students are introduced to the natural resources around them and the teacher extends this learning to students developing applications and solutions to real world problems (Ilhan \& Ekber Gülersoy, 2019). For example, student could develop solutions for preserving and caring for renewable and non-renewable 
natural resources, planting rare trees or flowers that could become extinct, and many other scenarios that introduce students to geographical thinking. Students can also complete scientific investigation-based geography studies that encourages students to investigate natural phenomena in their local environment. For example, students could be directed to map their thinking as they investigate a local problem, thus helping students to see that they have an important role in preserving nature (Hanifah et al., 2015; Higginbottom, 2016).

Based on data from midterm exam for social science subjects, especially geography at Junior High School (SMP Negeri 25 Semarang), each class demonstrates a low level of geographical knowledge. Indeed, more than $50 \%$ of grade 7 students (aged 13-14 years) have not yet reached the Minimum Completion Criteria $(K K M)$ targeted by the school. Of the 128 students in grade $7,58.59 \%$ scored below the KKM (see Table 1).

Table 1

Middle Semester Learning Outcomes of Class VII Students

\begin{tabular}{cccccc}
\hline Class & $\begin{array}{c}\text { Number of } \\
\text { Students }\end{array}$ & $\begin{array}{c}\text { Score below } \\
\text { KKM }\end{array}$ & $\begin{array}{c}\text { Percentag } \\
\text { e (\%) }\end{array}$ & $\begin{array}{c}\text { Score above } \\
\text { KKM }\end{array}$ & $\%$ \\
\hline VII A & 32 & 18 Students & $56.25 \%$ & 14 Students & $43.75 \%$ \\
\hline VII B & 31 & 20 Students & $64.51 \%$ & 11 Students & $35.48 \%$ \\
\hline VII C & 33 & 18 Students & $54.54 \%$ & 15 Students & $45.45 \%$ \\
\hline VII D & 32 & 19 Students & $59.37 \%$ & 13 Students & $40,62 \%$ \\
\hline Total & $\mathbf{1 2 8}$ & 75 Students & $\mathbf{5 8 . 5 9 \%}$ & 53 Students & $\mathbf{4 1 . 4 0 \%}$ \\
\hline
\end{tabular}

Source: Documentation of geography teacher at SMP Negeri 25 Semarang, 2019

To remedy this situation, it is important that teachers improve their implementation of quality learning model (Derlina, 2016; Gunawan et al., 2017; Rapi, 2016; Tesi \& Wilujeng, 2017). Specifically, this research study investigates the development of environment-based learning, the orientation of teaching through local problems and natural resources, which has been shown to be an effective approach to geography learning (Pratiwi et al., 2017; Sitorus et al., 2019).

Environment Based Learning (EBL) model optimizes student engagement by emphasizing group discussion activities so that students are active and responsible for their learning (Savin-Baden \& Major, 2004). The EBL model facilitates students' understanding of the content because student learning is based in their local environment. The goal is for students to learn through case studies or learning based on environmental issues to improve students' geography skills by thinking critically, innovatively, and creatively about phenomena in their environment, as well as to impact students' interest in geography. 


\section{Methodology}

\section{Research Design}

The type of this research is development research. This research develops the Environment Based Learning model at SMP Negeri 25 Semarang. Learning tools and resources developed include the syllabus, learning implementation plan, student modules, and supporting teaching materials such as PowerPoints. The research procedure included: (1)Analysis of learning concepts relevant to the learning theme; (2) Formulating learning objectives relevant to the learning theme based on the existing syllabus and Learning Implementation Plan (RPP); (3) Design of learning materials grounded in the Environment Based Learning model, such as the Learning Implementation Plan (RPP), syllabus, and student worksheets; (4) Analyzing Environment Based Learning model; (5) Examining the effectiveness of Environment Based Learning model; (6) Writing a developmental report on the Environment Based Learning implementation; and (7) Completing modifications to the final Environmental Base Learning module. The research procedure is shown in Figure 1. The research design was a one-group pretest-posttest design as shown in Table 2. The effectiveness of the model on students' learning was by questionnaires.

Table 2

One group pretest-posttest design

\begin{tabular}{lll}
\hline Before & Treatment & After \\
\hline $\mathrm{O}_{1}$ & $\mathrm{X}$ & $\mathrm{O}_{2}$ \\
\hline
\end{tabular}

Note :

$\mathrm{O}_{1}=$ pre-test before treatment with EBL model

$\mathrm{X}=$ Treatment with EBL model

$\mathrm{O}_{2}=$ post-test after treatment with EBL model

Increases in students' learning outcome were determined by the normalized gain equation as follows:

$$
\text { Normalized Gain score }(g)=\frac{\text { posttest score }- \text { pretest score }}{\text { maximum score }- \text { pretest score }}
$$

The gain score was used to determine the level of the students learning outcomes after being treated with EBL model. Table of N-Gain score category can be seen in Table 3.

Table 3

$N$-Gain score category (Hake, 1999)

\begin{tabular}{ll}
\hline Normalized Gain Score & Level \\
\hline $\mathrm{g}>0.7$ & High \\
\hline $0.7>\mathrm{g}>0.3$ & Medium \\
\hline $\mathrm{g}<0.3$ & Low \\
\hline
\end{tabular}


Hamid, N. et al. (2021). Development model for environment-based learning to improve junior high...

\begin{tabular}{|l|l|}
\hline $\begin{array}{l}\text { A preliminary } \\
\text { analysis: } \\
\text { Teachers } \\
\text { prepare } \\
\text { teaching }\end{array}$ & $\begin{array}{l}\text { Formulating and } \\
\text { compiling instruments, } \\
\text { namely the teacher } \\
\text { compiling a syllabus, } \\
\text { planning the } \\
\text { implementation of } \\
\text { learning with the EBL } \\
\text { model, discussion sheets, } \\
\text { student modules, and } \\
\text { power points. }\end{array}$ \\
\cline { 2 - 2 }
\end{tabular}

The design of
teaching materials
is developed with
characters:
courageous,
responsible, creative,
disciplined and
sensitive to the social
environment. With
knowledge, skills and
attitudes oriented to
the social
environment.

\begin{tabular}{|l|l|}
$\begin{array}{l}\text { model, discussion sheets, } \\
\text { student modules, and } \\
\text { power points. }\end{array}$ \\
\hline $\begin{array}{l}\text { Designing EBL } \\
\text { learning is to } \\
\text { concept and to } \\
\text { focus on problems } \\
\text { to be discussed }\end{array}$ & $\begin{array}{l}\text { Designing learning } \\
\text { activities with the EBL } \\
\text { model consists of 5 stages: }\end{array}$ \\
1. Facing the problem \\
2. Problem analysis \\
3. Discovery and reporting \\
4. Presentations and \\
solutions \\
5. Review and evaluation.
\end{tabular}

Designing learning strategies with methods to be used in EBL learning, group discussions, presentations for each group.
Implementation of Environment Based Learning model oriented to the social environment. The implementation is limited test to know about the quality of the model and field test with pre-experimental research to know the effectiveness of the model to increase students' learning outcome.

\begin{tabular}{|l|} 
Final result: student's \\
learning outcomes become \\
optimal through the case \\
study, students' geography \\
skills improve, students \\
become interested in \\
geography subjects, \\
students can think \\
critically, innovatively, and \\
solutions to the phenomena \\
around them
\end{tabular}

Figure 1. The research procedure

The data of pre-experimental research was analyzed using inferential statistical analysis by SPSS 16.0 with paired-sample t-test used to test the hypotheses. The use of paired-sample t-test was appropriate because this research used one class with a pre-test and post-test design; the data of pre-test and post-test result is paired because they come from the one same sample (Tyrrell, 2009). The criteria for $\mathrm{H}_{1}$ were accepted and $\mathrm{H}_{0}$ rejected was sig. (2-tailed) $<0.05$. The hypothesis in the preexperimental research were:

$\mathrm{H}_{0}$ : There is no significant increase in students learning outcomes after being treated with EBL model 
$\mathrm{H}_{1}$ : There is a significant increase in students learning outcomes after being treated with EBL model

\section{Participants}

The 128 grade 7 students at SMP 25 Semarang were grouped into four classes of students: grade 7A (32 students), grade 7B (31 students), grade 7C (33 students), and grade 7D (32 students). Grade 7B was purposefully selected for this study because this class had the largest number of students scoring below the Minimum Completed Criteria (KKM) as the goal of this study was to measure the effectiveness of the Environment Base Learning model in increasing students' geographical skills).

\section{Data Collection and Data Processing}

Multiple data sources informed the study. Direct observations (Yusuf, 2014) of students were made to understand their engagement during the Environment Based Learning module. Interviews (Muhajir, 2000) were conducted with geography teachers, principals, and some students to support the research findings and understand the initial conditions for the development of the Environment Based Learning module. Questionnaires (Muhajir, 2000; Yusuf, 2014) were used to find out the teacher and student reactions to the application of the Environment Based Learning model. Students were asked to complete a questionnaire of following following their experiences learning through the Environment Based Learning model. Other classroom artifacts (Darmawan, 2013) relevant to geography learning outcomes, such as student worksheets, and reference books used by SMP N 25 Semarang. Finally, a test (Yusuf, 2014) is used to know about the saws administered to measure student learning following the implementation of the Environment Base Learning model. The test that gives to collect the result base on the components of geographical skill, they are (1) asking geographic questions, (2) acquiring geographic information, (3) organizing geographic information, (4) analyzing geographic information, and (5) answering geographic questions (Bednarz et al., 1994).

Data were obtained from a validator who provided a descriptive analysis (Creswell, 2013; Muhajir, 2000; Yusuf, 2014) of the data sources. The results of the validator's assessment were used as input for revising and improving the teaching materials.

Data analysis of the student learning data used a paired-sample t-test of students' learning outcome. Analysis of the teacher and student questionnaires used descriptive statistics using an assessment guide that had been previously prepared by the researcher (Sudjana \& Ibrahim, 2008). 
Hamid, N. et al. (2021). Development model for environment-based learning to improve junior high...

\section{Findings}

\section{Planning and Validation of Learning Resources Stage}

This development stage included expert validation by geography teachers and lecturers (see Table 4).

Table 4

Learning Model Validator for Environment Based Learning

\begin{tabular}{lll}
\hline No. & Validator & Code \\
\hline 1. & Lecturer from Universitas Negeri Semarang & V1 \\
\hline 2. & Lecturer from Universitas Negeri Semarang & V2 \\
\hline 3. & Headmaster from SMP N 25 Semarang & V3 \\
\hline 4. & Social studies teacher from SMP N 25 Semarang & V4 \\
\hline 5. & Social studies teacher from SMP N 25 Semarang & V5 \\
\hline
\end{tabular}

The assessments carried out by the validators included the following indicators: 1) the format of material or material organization; 2) learning syllabus design; 3 ) the design of learning activities; and 4) the design of the learning module. The researcher made revisions following the validator's suggestions and discussion. The validation results are in the form of the feasibility of the corrections, the suggestions were used as improvements and revisions to the learning model and the teaching materials.

The syllabus was the first step used to guide learning development. This is important because the syllabus delineates the specific learning objectives to be achieved. The results of the syllabus assessment are displayed in Table 5.

Table 5

Recapitulation of Syllabus Assessments by Validators

\begin{tabular}{|c|c|c|c|c|c|c|c|c|c|}
\hline \multirow{2}{*}{$\begin{array}{l}\mathrm{N} \\
\mathrm{O}\end{array}$} & \multirow{2}{*}{$\begin{array}{l}\text { Assessed aspects of the } \\
\text { syllabus }\end{array}$} & \multicolumn{5}{|c|}{ Validator } & \multirow{2}{*}{$\begin{array}{l}\text { Numb } \\
\text { er }\end{array}$} & \multirow{2}{*}{$\begin{array}{l}\text { Aver } \\
\text { age }\end{array}$} & \multirow{2}{*}{$\begin{array}{l}\text { Asses } \\
\text { sment }\end{array}$} \\
\hline & & 1 & 2 & 3 & 4 & 5 & & & \\
\hline & $\begin{array}{l}\text { Completeness of } \\
\text { syllabus components }\end{array}$ & 3 & 4 & 4 & 4 & 4 & 19 & 3.8 & SB \\
\hline & Competency standard & 4 & 4 & 4 & 4 & 4 & 20 & 4.0 & SB \\
\hline & Basic competency & 4 & 4 & 3 & 4 & 4 & 19 & 3.8 & SB \\
\hline & Indicator & 3 & 4 & 4 & 3 & 4 & 18 & 3.6 & SB \\
\hline & Learning Activity & 4 & 4 & 4 & 4 & 4 & 20 & 4.0 & SB \\
\hline & Learning material & 3 & 4 & 3 & 4 & 3 & 17 & 3.4 & SB \\
\hline & $\begin{array}{l}\text { Learning methods and } \\
\text { activity }\end{array}$ & 4 & 4 & 4 & 4 & 4 & 20 & 4.0 & SB \\
\hline & Assessment standard & 3 & 3 & 3 & 4 & 4 & 17 & 3.4 & SB \\
\hline & Time Allocation & 3 & 4 & 4 & 4 & 4 & 19 & 3.8 & SB \\
\hline & Language & 4 & 4 & 4 & 4 & 4 & 20 & 4.0 & SB \\
\hline & Total & 35 & 39 & 37 & 39 & 39 & & 37.8 & \\
\hline & Overall average & & & & & & & 3.78 & \\
\hline & Validator average & 87.5 & 97.5 & 92.5 & 97.5 & 97.5 & 472.5 & 94.5 & SB \\
\hline
\end{tabular}

Note : SB = Very Good

Description: Very good category can be used with slight revisions 
The overall syllabus score was an average of 3.78, meaning that the syllabus was independently assessed to be very good. The validators also provided suggestions to complete the learning resource. Of the ten aspects assessed, there were four categories with a value of four (very satisfactory). These four aspects were competency standards, learning activities, methods and activities in learning, and language. For the overall aspect, the first validator gave an average score of 87.7; the second gave an average score of 97.5; the third gave an average score of 92.5; the fourth validator gave an average score of 97.5 and the last gave an average score of 97.5. Overall, each validator scored highly and offered few revisions.

Similarly, the lesson plans were also validated by the independent experts. Of the twelve indicators, four indicators scored very high - identity, competency standards, learning activities, and time allocation (see Table 6).

Table 6

Summary of the Assessment of the Learning Implementation Plan by the Validator

\begin{tabular}{llllllllll}
\hline $\begin{array}{l}\mathrm{N} \\
\mathrm{o}\end{array}$ & $\begin{array}{l}\text { The assessed aspects } \\
\text { of the syllabus }\end{array}$ & $\begin{array}{l}\text { Validator } \\
\text { 1 }\end{array}$ & 2 & 3 & 4 & 5 & $\begin{array}{l}\text { Num } \\
\text { ber }\end{array}$ & $\begin{array}{l}\text { Aver } \\
\text { age }\end{array}$ & $\begin{array}{l}\text { Asse } \\
\text { ssm } \\
\text { ent }\end{array}$ \\
\hline $\begin{array}{l}\text { Completeness of } \\
\text { syllabus component }\end{array}$ & 3 & 4 & 4 & 4 & 4 & 19 & 3.8 & SB \\
\hline Identity & 4 & 4 & 4 & 4 & 4 & 20 & 4.0 & SB \\
\hline Competency standard & 4 & 4 & 4 & 4 & 4 & 20 & 4.0 & SB \\
\hline Basic competency & 3 & 3 & 3 & 4 & 4 & 17 & 3.4 & SB \\
\hline Indicator & 4 & 4 & 4 & 3 & 4 & 19 & 3.8 & SB \\
\hline Learning material & 3 & 4 & 3 & 4 & 4 & 18 & 3.6 & SB \\
\hline Learning activity & 4 & 4 & 4 & 4 & 4 & 20 & 4.0 & SB \\
\hline $\begin{array}{l}\text { Learning methods and } \\
\text { activity }\end{array}$ & 3 & 4 & 4 & 4 & 4 & 19 & 3.8 & SB \\
\hline Assessment standard & 4 & 3 & 3 & 4 & 3 & 17 & 3.4 & SB \\
\hline $\begin{array}{l}\text { Learning tools and } \\
\text { resource }\end{array}$ & 4 & 4 & 3 & 3 & 4 & 18 & 3.6 & SB \\
\hline Time Allocation & 4 & 4 & 4 & 4 & 4 & 20 & 4.0 & SB \\
\hline Language & 4 & 3 & 4 & 4 & 3 & 18 & 3.6 & SB \\
\hline Total & 44 & 45 & 44 & 46 & 46 & & 45 & \\
\hline Overall average & & & & & & & 4.5 & \\
\hline Validator average & 91.6 & 93.7 & 91.6 & 95.8 & 95.8 & 93.7 & & SB \\
\hline
\end{tabular}

Note : SB = Very Good

Description: Very good category can be used with slight revisions

The overall average scores were 91.6, 93.7, 91.6 and 95.5 respectively. The validators also gave suggestions for the teaching materials developed. Overall, each validator scored very highly and offered only a few revisions. Next to be validated was the student module assessment. Table 7 shares a summary of the student module assessments. 
Hamid, N. et al. (2021). Development model for environment-based learning to improve junior high...

Table 7

Summary of Module Assessments by Validators

\begin{tabular}{|c|c|c|c|c|c|c|c|c|}
\hline \multirow{2}{*}{ No } & \multirow{2}{*}{ The assessment aspect } & \multicolumn{5}{|c|}{ Validator } & \multirow{2}{*}{$\begin{array}{l}\text { Avera } \\
\text { ge }\end{array}$} & \multirow{2}{*}{$\begin{array}{l}\text { Cate } \\
\text { gory }\end{array}$} \\
\hline & & 1 & 2 & 3 & 4 & 5 & & \\
\hline & \multicolumn{8}{|l|}{ Content Eligibility Components } \\
\hline 1. & Learning material & 3 & 4 & 4 & 4 & 3 & 3.6 & SB \\
\hline 2. & Learning concept & 3 & 4 & 4 & 3 & 4 & 3.6 & SB \\
\hline \multirow[t]{2}{*}{3.} & The learning method used & 4 & 4 & 3 & 4 & 4 & 3.8 & SB \\
\hline & \multicolumn{8}{|l|}{ Language Components } \\
\hline 4. & $\begin{array}{l}\text { Being able to be understood by } \\
\text { the students }\end{array}$ & 4 & 4 & 3 & 4 & 4 & 3.8 & SB \\
\hline 5. & $\begin{array}{l}\text { Encouraging students to think } \\
\text { critically }\end{array}$ & 3 & 3 & 4 & 4 & 4 & 3.6 & SB \\
\hline 6. & Using sentence structure & 3 & 4 & 4 & 4 & 3 & 3.6 & SB \\
\hline 7. & Using the standard term & 4 & 3 & 4 & 3 & 4 & 3.6 & SB \\
\hline 8. & Good and correct grammar & 4 & 4 & 4 & 4 & 4 & 4.0 & SB \\
\hline \multirow[t]{2}{*}{9.} & Spelling Usage & 4 & 4 & 4 & 4 & 4 & 4.0 & SB \\
\hline & \multicolumn{8}{|l|}{ Presentation Components } \\
\hline 10 & Consistent module presentation & 3 & 4 & 4 & 3 & 4 & 3.6 & SB \\
\hline 11 & $\begin{array}{l}\text { Coherent presentation } \\
\text { modules }\end{array}$ & 4 & 4 & 4 & 4 & 4 & 4.0 & SB \\
\hline 12 & Systematic module presentation & 4 & 4 & 4 & 4 & 4 & 4.0 & SB \\
\hline 13 & Student centered & 3 & 3 & 3 & 4 & 4 & 3.4 & SB \\
\hline 14 & Interactive communication & 4 & 4 & 4 & 3 & 3 & 3.6 & SB \\
\hline \multirow[t]{4}{*}{15} & $\begin{array}{l}\text { Accordance with the character } \\
\text { of the subject }\end{array}$ & 4 & 4 & 4 & 4 & 4 & 4.0 & SB \\
\hline & Total & 54 & 57 & 57 & 56 & 57 & 56.2 & \\
\hline & Overall average & & & & & & 3.74 & SB \\
\hline & Validator average & 90 & 95 & 95 & 93 & 95 & 93.6 & SB \\
\hline
\end{tabular}

The overall average of 3.74, means that the module is was ranked as very good. Four categories received very good scores: good and correct grammar, spelling usage, coherent module presentation, systematic module presentation, and accordance with the character of the subjects.

Although the results of the assessment of each aspect was categorized as very good, there was some input from the validators to improve the module. Researchers immediately used this feedback to improve the teaching materials. The validators comments and suggestions a can be summarized and the researcher's responses are summarized in Table 8. 
Table 8

Expert Input (Validator)

\begin{tabular}{|c|c|c|c|}
\hline No & $\begin{array}{l}\text { Teaching } \\
\text { Materials }\end{array}$ & Validator input & Follow-up \\
\hline \multirow[t]{3}{*}{1.} & Syllabus & $\begin{array}{l}\text { Indicators of achievement } \\
\text { must be measured and } \\
\text { described in learning } \\
\text { activities }\end{array}$ & $\begin{array}{l}\text { The indicator had been likened } \\
\text { to the standard of competence } \\
\text { and learning activities }\end{array}$ \\
\hline & & Use clear language & Clarified the language used. \\
\hline & & $\begin{array}{l}\text { Time allocation is displayed } \\
\text { and detailed }\end{array}$ & $\begin{array}{l}\text { Made allocation more detail to } \\
\text { be clearer }\end{array}$ \\
\hline \multirow[t]{3}{*}{2.} & $\begin{array}{l}\text { A lesson } \\
\text { implementation } \\
\text { plan }\end{array}$ & $\begin{array}{l}\text { The indicator uses an } \\
\text { operational verb and is } \\
\text { adapted to the syllabus. }\end{array}$ & $\begin{array}{l}\text { The indicator had been revised } \\
\text { according to the syllabus }\end{array}$ \\
\hline & & $\begin{array}{l}\text { The material is adjusted } \\
\text { according to the indicator }\end{array}$ & $\begin{array}{l}\text { The material was adjusted to } \\
\text { indicators and added with an } \\
\text { explanation as an introduction } \\
\text { to stimulate student knowledge }\end{array}$ \\
\hline & & $\begin{array}{l}\text { Language and source } \\
\text { should be equipped }\end{array}$ & $\begin{array}{l}\text { Some word improvements then } \\
\text { wrote the sources }\end{array}$ \\
\hline \multirow[t]{3}{*}{3} & Student Module & Images should be enlarged & $\begin{array}{l}\text { Images were defined and sized } \\
\text { proportionately }\end{array}$ \\
\hline & & Simplify the language & $\begin{array}{l}\text { The use of language was } \\
\text { simplified }\end{array}$ \\
\hline & & $\begin{array}{l}\text { There is no table of } \\
\text { contents }\end{array}$ & A content list was created \\
\hline
\end{tabular}

\section{Development Stage of Environment Based Learning Tools}

Syllabus. The syllabus was used as a guideline for further development of learning, such as making a learning plan, managing learning activities and developing an assessment system. Syllabus development is the first and most fundamental task to be completed so that learning objectives can be achieved as intended by the developers. Following the general assessment and comments of the validators, the revisions of the draft syllabus emphasized aspects of the syllabus content. Specifically, that achievement indicators must be measured and described in the learning activities, the language used, and time allocations.

Learning implementation plan (RPP). The lesson plan is the teacher's guide for teaching in the classroom. The lesson plan makes sure that teaching is in accordance with the relevant competency standards and basic competencies. The researcher made the RPP following the Environment Based Learning model oriented to the social environment. The general assessment and feedback from the validators emphasized aspects of the learning implementation plan. Specifically, that the achievement indicators must be measured and described in learning activities, the material was adjusted to align with the indicators. and resources used in learning were completed. 
Student Module. The student module is a student guide book that supports the implementation of the learning process, thus making sure that the content was in accordance with the objectives, the language easy to understand, and the presence of picture to attract students. Input from the validators suggested the need for bigger pictures to make it interesting, simplification of the language, and the addition of a table of contents to make it easier to navigate. The student module was deemed to fulfill the elements of fostering natural attitudes, including fostering curiosity, increasing problem-solving abilities, applying the knowledge students already have in real life and being sensitive to the social environment.

\section{Implementation Stage of Learning Tool Results with a Learning Model Environment Based Learning}

After the planning and validation stages of learning resources, the Environment Based Learning module implemented. Before being tested on a broad scale, the learning model was piloted with 16 students who were randomly selected for participation in the pilot. The 16 students consisted of 4 students of class 7A, 4 students of class 7B, 4 students of class 7C, and 4 students of class 7D. This pilot further informed the appropriate implementation of the learning model. The learning model was then applied in the classroom, specifically with class 7B (31 students) using a one-group pretest-posttest design. The students were given a pretest before they get EBL model to know about their beginning ability. After that, they got a treatment using EBL model, and then they was gave posttest to know about their ability after treated. The descriptive statistics of the pre- and post-test are shown in table 9.

Table 9

Descriptive Statistic of Students 'Pre and Post-Test Learning Outcomes

\begin{tabular}{llllll}
\hline Stage & N & Min. & Max. & Mean & Std. Deviation \\
\hline Pre-test & 32 & 58 & 85 & 69,72 & 7,113 \\
\hline Post-test & 32 & 75 & 97 & 86,66 & 5,677 \\
\hline
\end{tabular}

The results show that students learning outcomes increased after treatment using the EBL model. The N-gain score is 0.621 , which places learning gains in the medium category $(0.31<0.621<0.70)$.

One-way analysis of variance was used to determine significance of the learning gains. First, prerequisite tests for homogeneity and normality were completed. The normality test used the one-sample Kolmogorov test and showed that the Sig. (2tailed) of normality test is 0,793 (more than .050), so the data is normally distributed. The result of homogeneity test, using the levene test, showed that the Sig. is 0,321 (more than 0,05 ), so the data is homogeneous. Thus, the prerequisites of normality and homogeneity were fulfilled. The results of the paired-sample t-test are shown in Table 10. As the sig. value of paired-sample $t$-test is $0.000(\mathrm{t}=-19,252$, sig. $<0,05), \mathrm{H}_{0}$ is rejected and $\mathrm{H}_{1}$ is accepted. The students' learning outcomes increased significantly following treatment with the EBL model. 
Table 10

The Result of Paired-Sample T-Test

\begin{tabular}{lllll}
\hline & $\mathrm{t}$ & $\mathrm{df}$ & Sig. $(2$ tailed $)$ & Conclusion \\
\hline Pretest-Posttest & -19.152 & 31 & 0.000 & $\mathrm{H}_{0}$ rejected \\
\hline
\end{tabular}

In Table 11 below, the researcher describes the learning process before and after using EBL at SMP Negeri 25 Semarang.

Table 11

Traditional Lecture Based (Before EBL) and Learning Using EBL

\begin{tabular}{|c|c|c|c|}
\hline No & $\begin{array}{l}\text { Assessme } \\
\text { nt aspects }\end{array}$ & $\begin{array}{l}\text { Traditional Lecture Based } \\
\text { (Before EBL) }\end{array}$ & Learning using EBL \\
\hline & $\begin{array}{l}\text { Learning } \\
\text { activities }\end{array}$ & $\begin{array}{l}\text { A teacher is still fully } \\
\text { involved in the teaching and } \\
\text { learning process so that } \\
\text { students are less active in } \\
\text { learning }\end{array}$ & $\begin{array}{l}\text { The teacher is just as a facilitator } \\
\text { and makes students fully involved in } \\
\text { the teaching and learning process so } \\
\text { that all students are active in } \\
\text { learning }\end{array}$ \\
\hline & Method & $\begin{array}{l}\text { The methods used are } \\
\text { lectures, as well as } \\
\text { assignments and exercises }\end{array}$ & $\begin{array}{l}\text { Applying the EBL method, which } \\
\text { includes } 5 \text { stages, namely: facing } \\
\text { problems, problem analysis, } \\
\text { discovery and reporting, } \\
\text { presentation and solutions, and } \\
\text { evaluation. }\end{array}$ \\
\hline & Activeness & $\begin{array}{l}\text { The activeness of students in } \\
\text { learning activities has not } \\
\text { been maximal }\end{array}$ & $\begin{array}{l}\text { Almost every student is active in } \\
\text { learning, seen from many students } \\
\text { who ask questions and opinions, } \\
\text { give statements and provide } \\
\text { solutions to problems in case } \\
\text { studies. }\end{array}$ \\
\hline & $\begin{array}{l}\text { Student } \\
\text { handbook }\end{array}$ & $\begin{array}{l}\text { Package book, this package } \\
\text { book has lack of clear images }\end{array}$ & $\begin{array}{l}\text { Book packages and student modules } \\
\text { that have clear pictures, which can } \\
\text { attract students to read them. }\end{array}$ \\
\hline & Learning & Learning is still theoretical & $\begin{array}{l}\text { Learning provides direct experience } \\
\text { to interact with the social } \\
\text { environment. It is fun and students } \\
\text { become enthusiastic in learning. }\end{array}$ \\
\hline
\end{tabular}

The problem addressed in this study was to improve students' learning of geography concepts and skills through the development and implementation of EBL model. The sequence of activities in the EBL model included:

Preliminary stage. The goal of this stage is to motivate student learning by activating prior knowledge. In addition, the teacher greets students, appoints a prayer leader and takes attendance as normal.

Core Activity. At this stage, the teacher places students into groups and carries out learning activities of the EBL lessons. This state includes (a) solving problems, the teacher presents a problem based on the local environment.; (b) Problem Analysis, the teacher invites students to analyse the environmental problems on the discussion worksheet; (c) Discovery and reporting, students discuss their opinions 
and document them on the discussion worksheet and come to consensus on the best solution.; (d) Reporting presentations and solutions: the student groups present their solution to the whole class. (e) Reviewing and evaluating: students reflect on different opinions presented, and the teacher evaluates the group presentations.

Final activity. The final activity carried out by the teacher is evaluating then reinforcing the material and closing the lesson. The steps that constitute the stages of the improvement process included:

\section{Lesson Preparation}

This step is occurred over several phases before carrying out all the learning actions in the classroom. In the learning process in the classroom, researchers firstly prepare some supporting things such as the Learning Implementation Plan (RPP), all the teaching materials related to the material, discussion sheets, power points, EBL modules and activity plans at the end of the learning. The stage that a teacher must do before doing the learning process is to make preparations related to the material that will be delivered in the classroom.

\section{Learning Implementation of EBL Model}

The learning process of Environment Based Learning consists of 5 stages: facing problems, problem analysis, discovery and reporting, presentation, review and evaluation.

Facing problem. The role of the teacher in this phase is to present a problem, which includes (1) Presentation of problems related to the social environment; (2) facilitating student discussion of the problem; (3) explaining the learning objectives; and (4) motivating students to be actively involved. This stage shown in figure 2.

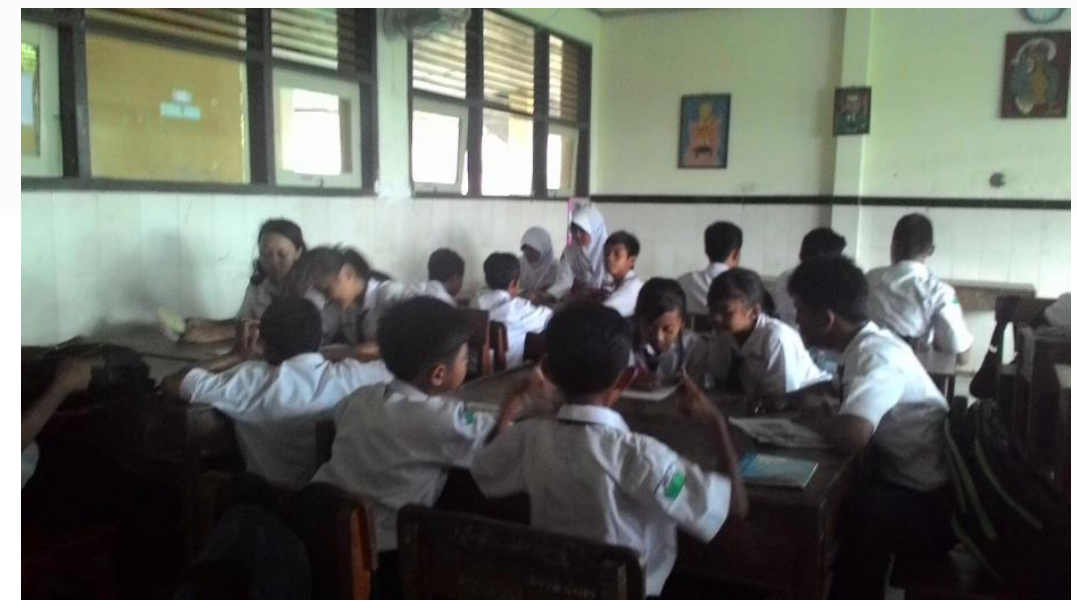

Figure 2. Students are implementing a case study in the EBL learning model

Problem analysis. The teacher's role in the problem analysis phase is: (1) establishing mixed ability student groups of 5-6 students; (2) helping students to carry out investigations to understand and solve problems; (3) facilitating students 
in accessing the necessary information and resources. This stage shown in figure 3 below.

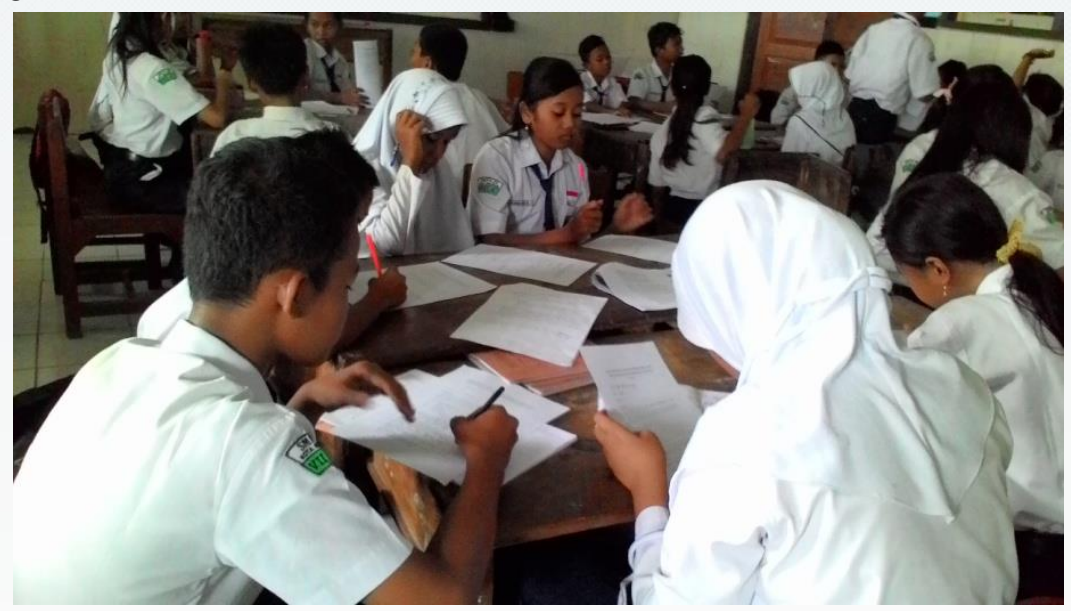

Figure 3. Students are analyzing problems in the EBL learning model

Discovering and Reporting. In the discovering and reporting phase, the teacher encourages students to obtain appropriate information. Students seek information from libraries, books and other sources. Students carry out discussion activities and exchange ideas within their group and work towards a consensus solution. Figure 4 below shows the stage.

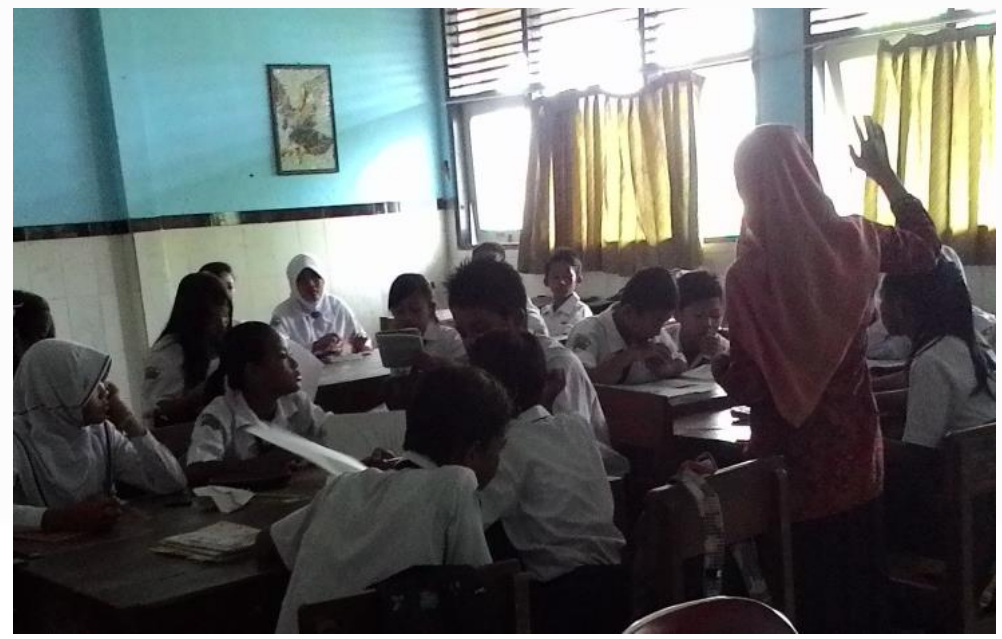

Figure 4. Students are finding and reporting the discussed problems

Presentations and solutions. In this phase, each group present their work to the whole class. A student is appointed to be the chairperson and represents their group's discussion to the class. All students are responsible for providing suggestions, responses and solutions to questions from other groups. This stage shown in figure 5 below. 


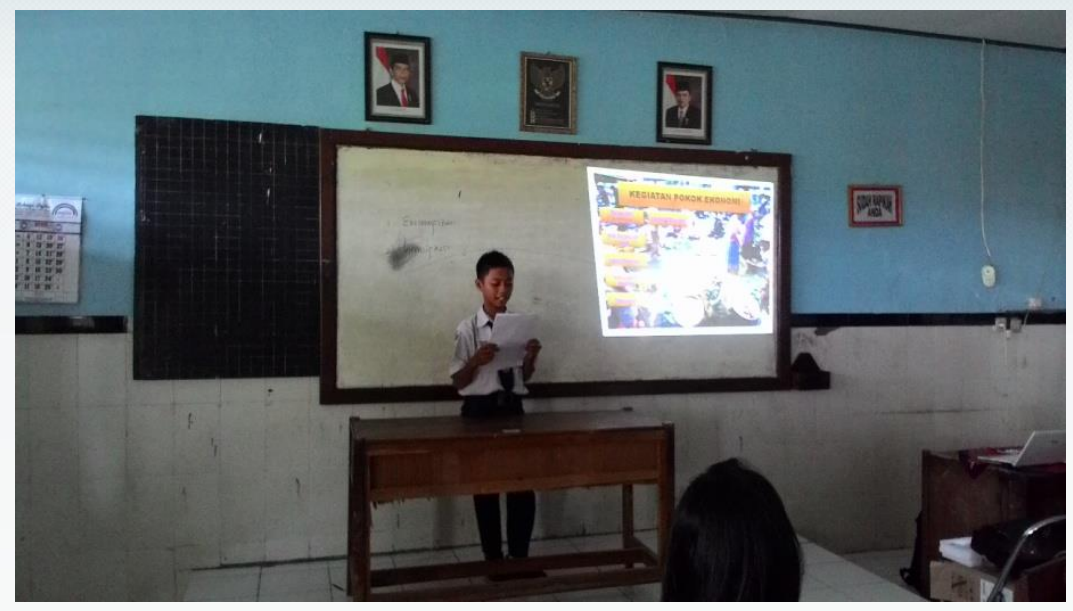

Figure 5. Students presenting the results of the discussion

Review and evaluation. In the review and evaluation phase, the role of teacher is to conclude the groups presentations. The teacher evaluates the presentations and conducts a final evaluation to determine the extent of the student's level of understanding.

\section{Discussion}

Learning is a process that begins with activity and ends with a reaction to facing new situations that can change the characteristics of children according to their maturity. Psychologically, learning is a mental process in which there are mental functions that must be developed. Among them are thinking, interest, ability to be sensitive to the environment and so on, all of which can be applied using environment-based learning (Barrow \& Woods, 2006; Black et al., 2003). Environmental-based learning promotes students to think critically about the phenomena around them by providing solutions to overcome existing problems. Students are invited to think of solutions using certain media that can attract students' interest in learning, this can improve their geography skills (Adanalı\& Alim, 2017, 2019).

The environment-based learning model has several advantages, including: (1) Problem solving is a comparatively good technique to better understand the content of the lesson; (2) It can challenge students' abilities and provide satisfaction to find new knowledge for students; (4) It can increase student learning activities; (5) It can help students how to transfer knowledge to understand problems in real life; (6) It can help students develop new knowledge and be responsible for the learning activities; (7) Through problem-solving, it can be shown that every subject is basically a way of thinking for students to understand something that is not just from the teacher or books; (8) It is seen as more fun and liked by students; (9) It can develop students' ability to think critically and develop their ability to adapt to new knowledge; (10) It can provide opportunities for students to apply the knowledge they already have in the real world.

Based on this study, the environment-based learning model has the advantage of optimizing student learning through case studies and learning based on environmental 
problems, for example natural resources, sustainable tourism, and pollutions (Aly et al., 2021). Students independently analyzed problems related to natural resources, classified natural resources as renewable and non-renewable, and finally provide solutions for conserving these natural resources. This was in contrast to traditional teaching previously experienced by these students where they read geography books without practice or application.

The results of this research show that students can improve their geographic skills through engagement in an EBL model. Base on the findings, the EBL implementation resulted in an increase in students' learning outcomes within the medium category of $\mathrm{N}$-gain. This result inform that the students' geographical skill, they are skill in asking geographic questions, acquiring geographic information, organizing geographic information, analyzing geographic information, and answering geographic questions increase. It is known from the mean of students' score that increase from 69,72 in pre-test to 86,66 in post-test. This parallels other results from the literature (e.g. Adanali \& Alim, 2017, 2019; Hanifah et al., 2015; Seyhan, 2019. Through EBL, students are able to see the application of content that they would otherwise just read about in a textbook (Fögele, 2015; Higginbottom, 2016; Kayaalp et al., 2020).

This study also demonstrates students' interest in analyzing natural resources, thinking critically, innovatively, and creatively about these phenomena and proposing local solutions. Whereas previously, students thought about geography as learning to memorize country names, capital names, the names of natural resources, etc. Through EBL, they find it easier to understand geography lessons by thinking scientifically, discussing with fellow students and teachers, seeking knowledge from books and the internet, and applying this knowledge to their surroundings. This type of thinking in geography skills must be pursued from an early age so that students appreciate geography education for the sake of civilization and the sustainability of their natural surroundings (Akkaya Yilmaz \& Karakuş, 2018; Larsen \& Harrington, 2019).

The environment-based learning model can increase students' interest and ability to continue learning even after class activities finish. There are many advantages of environment-based learning model that motivate children to study hard. Innovative learning with a social environment-oriented learning model requires active participation from students. These methods include (1) sharing information by brainstorming, collaboration, group discussion, and seminars; (2) learning from experience by simulation, role-playing, and games; (3) learning through problemsolving by case studies and workshops.

Learning methods with a social environment-oriented learning model challenge students to be able to make decisions effectively using geographical concepts. The environmental-based learning model is socially oriented such that students must participate actively, always be challenged to have critical power, be able to collaboratively analyze and solve problems related to their local setting (Demarrais \& Lapan, 2004). Teacher competence to support the learning model process of social 
environment based learning is needed. Thus, it is critical to improve the knowledge, understanding, and skills of teachers as facilitators in student-centered learning.

The development of an environment-based learning model with a social environment orientation showed positive results for student learning. The EBL teaching materials are designed to provide cognitive, affective, and psychomotor assessments through social environment-oriented learning activities. In addition, students are provided with direct experience and encouraged to construct an understanding of the concepts being studied (Gunawan et al., 2017). These findings are also supported by the results of the validator's assessment ratings. This study found a social environment-oriented learning model to be a positive driver of student learning.

The EBL materials developed in this study helped students to understand lessons about the environment (Rapi, 2016). Students can learn actively through a discussion process using the EBL model. Students' responses to learning activities and learning outcomes were demonstrated by the number of students asking questions during the learning activities, responding critically to concepts and solutions, and analyzing the problems within the local environment (Tesi \& Wilujeng, 2017)..

\section{Conclusion and Recommendations}

Choosing the right learning model for students is very important for providing students with the skills to think critically, innovatively, and to develop solutions. Currently, geography teachers have a difficult task to engaging and motivating students in learning geography, as students think that geography lessons are boring lessons based on memorization. This requires the selection of a new learning model that is more engaging for students.

The environment-based learning model invites students to recognize, discover, analyze, and provide solutions to the natural phenomena around them. By implementing EBL model, the geography skills for students aged 13-14 year can be improved. At this age, students have thoughts of exploring the natural surroundings, so the combination of geography theory with the practice of analyzing spatial abilities in geography, can improve students' skills to think geographically in environmental terms within a spatial context.

The hope is that with this research, geography teachers can further develop learning models based on the social environment to allow students to be active in critical thinking. In addition, it is necessary to develop an environment-based curriculum that aims to introduce students to the ability to think geographically from an early age. For example, the ability to manage natural resources around them, the ability to deal with disasters in their surroundings, and the ability to infer new knowledge that comes from the natural surroundings. 


\section{References}

Adanall, R., \& Alim, M. (2017). The views of preservice teachers for problem based learning model supported by geocaching in environmental education. Review of International Geographical Education Online, 7(3), 264-292.

Adanali, R., \& Alim, M. (2019). The students' behaviours at the instructional geocaching applied in problem-based environmental education. Review of International Geographical Education Online, 9(1), 122-148. https://doi.org/10.33403/rigeo.573478.

Akkaya Yilmaz, M., \& Karakuş, U. (2018). The impact of place based education approach on student achievement in social studies. Review of International Geographical Education Online, 8(3), 500-516. https://doi.org/10.33403/rigeo.505261.

Aly, M.N., Hamid, N., Suharno, N.E., Kholis, N., Aroyandini, E.N. (2021). Community Involvement and Sustainable Cave Tourism Development in Tulungagung Region. Journal of Environmental Management and Tourism, 12(2), 588-597. https://doi.org/10.14505//jemt.v12.2(50).28.

Barrow, R., \& Woods, R. (2006). An Introduction to Philosophy of Education (4th ed.). Routledge.

Bednarz, S. M., Bettis, N. C., Boehm, R. G., De Souza, A. R., Downs, R. M., Marran, J. F., . . Salter, C. L. (1994). Geography for Life National Geography Standards 1994: Geography Education Standards Project. National Geographic Research \& Exploration.

Black, N., Smeyer, P., Smith, R., \& Standish, P. (2003). Philosophy of Education. Blackwell Publishing Ltd.

Creswell, J. W. (2013). Research Design Pendekatan Kualitatif, Kuantitatif, dan Mixed (A. Fawaid (ed.)). Pustaka Pelajar.

Darmawan, D. (2013). Metode Penelitian Kuantitatif. PT. Remaja Rosdakarya.

DeMarrais, K., \& Lapan, S. D. (2004). Foundations for Research - Methods of Inquiry in Education and the Social Science. Lawrence Erlbaum Associates.

Derlina, \& Nst, L. A. (2016). Efek Penggunaan Model Pembelajaran Inquiry Training Berbantuan Media Visual dan Kreativitas Terhadap Keterampilan Proses Sains Siswa. Cakrawala Pendidikan, 35(2), 153-163. https://doi.org/10.21831/cp.v15i2.8080

Dukomalamo, K., \& Amelia, R. N. (2019). Penerapan Model Pembelajaran Problem Based Learning Untuk Meningkatkan Hasil Belajar Siswa Pada Materi Interaksi Antarnegara Asia dan Negara Lainnya Mata Pelajaran IPS Di Kelas IX-B SMP Negeri 1 Kota Ternate. Pangea Jurnal Geografi, 20 1(1), https://doi.org/10.1017/CB09781107415324.004

Faiz, M., \& Avci, E. K. (2020). Academic motivation levels of secondary school students and their attitudes towards a social studies course. Review of International Geographical Education Online, 10(2), 156-185. https://doi.org/10.33403/rigeo.693769

Fögele, J. (2015). Implementing Geographical Key Concepts: Design of a Symbiotic Teacher Training Course Based on Empirical and Theoretical Evidence. Review of International Geographical Education Online, 5(1), 56-76.

Gunawan, G., Sahidu, H., Harjono, A., \& Suranti, N. M. Y. (2017). The Effect of Project Based Learning with Virtual Media Assistance on Student's Creativity in Physics. Cakrawala Pendidikan, 36(2), 167-179.

Hake, R. R. (1999). Analyzing Change/Gain Scores. Dept. of Physics, Indiana University. 
Hakim, Z. R., \& Riyani, E. (2015). Penerapan Model Pembelajaran Problem Based Learning Pada Mata Pelajaran IPS. 1(2), 143-162.

Hamid, N., Wijayanti, N. R., Yaqin, M. A., \& Ningsih, M. P. (2020). Implementation of problem based learning model on social science subject on junior high school students in Semarang, Indonesia. International Journal of Psychosocial Rehabilitation, 24(7), 9735-9743. https://doi.org/10.37200/IJPR/V24I7/PR270976

Hanifah, M., Shaharudin, I., Mohmadisa, H., Nasir, N., \& Yazid, S. (2015). Transforming Sustainability Development Education in Malaysian Schools through Greening Activities. Review of International Geographical Education Online, 5(1), 77-94.

Higginbottom, T. (2016). Geography through Enquiry: Approaches to Teaching and Learning in the Secondary School. Geography, 101, 55.missing pages

Ilhan, A., \& Ekber Gülersoy, A. (2019). Discovery learning strategy in geographical education: A sample of lesson design. Review of International Geographical Education Online, 9(3), 523-541. https://doi.org/10.33403/rigeo.672975

Kayaalp, F., Meral, E., Şimsek, U., \& Şahin, İ. F. (2020). A Search for a Method to Improve Critical Thinking Skills in Social Studies Teaching: Writing-to-Learn. Review of International Geographical Education Online, 10(3), 400-430. https://doi.org/10.33403/rigeo.719222

Kusumawat, W. (2015). Penerapan Model Problem Based Learning Pada Mata Pelajaran IPS Untuk Meningkatkan Hasil Belajar Siswa Kelas Vi SDN Semboro 01 Kecamatan Semboro Kabupaten Jember Tahun Ajaran 2014/2015. Pancaran, 4(4), 1-12.

Larsen, T. B., \& Harrington, J. (2019). Learning progressions, paradigms, and geographic thinking in the anthropocene. Review of International Geographical Education Online, 9(3), 542-556. https://doi.org/10.33403/rigeo.561562

Mu'aini, M. (2016). Peningkatan Kualitas Pembelajaran IPS Melalui Penerapan Metode Problem Based Learning di Smp Negeri 15 Kota Yogyakarta. JIPSINDO, 3(1), 44-62.

Muhajir, N. (2000). Metode Penelitian Kualitatif. Rake Sarasin.

Mustofani, T. M., \& Hartinah, I. (2019). Modifikasi Model Pembelajaran Problem Based Learning (PBL) Dengan Strategi Pembelajaran Tugas. Prosiding Seminar Nasional Pendidikan KALUNI, 2, 605-616. https://doi.org/10.30998/prokaluni.v2i0.100

Pasongli, H., Marthinu, E., \& Walanda, R. S. (2020). Peningkatan Hasil Belajar IPS Geografi Melalui Penerapan Model Pembelajaran Problem Based Learning Di SMP Negeri 5 Kota Ternate. Jurnal Penelitian Pendidikan Geografi, 5(1), 62-70. http://ojs.uho.ac.id/index.php/ppg/article/view/11213

Pratiwi, P. H., Hidayah, N., \& Martiana, A. (2017). Pengembangan Modul Mata Kuliah Penilaian Pembelajaran Sosiologi Berorientasi HOTS (Higher Order Thinking Skills). Cakrawala Pendidikan, 36(2), 201-209. https://doi.org/10.21831/cp.v36i2.13123

Rapi, N. K. (2016). Pengaruh Model Pembelajaran dan Jenis Penilaian Formatif Terhadap Hasil Belajar IPA Siswa SMPN. Cakrawala Pendidikan, 35(1), 69-79. https://doi.org/10.21831/cp.v1i1.8366

Rochmawati, H. A., \& Siradjuddin, S. (2018). Penerapan Model Pembelajaran Problem Based Learning Untuk Meningkatkan Hasil Belajar Pada Pelajaran IPS Kelas V SD Iskandar Said Surabaya. Jurnal Penelitian Pendidikan Guru Sekolah Dasar, 5(1), 1-10.

Savin-Baden, M., \& Major, C. H. (2004). Foundations of Problem-based Learning. Open University Press. 
Seyhan, A. (2019). Out-of-school learning to achieve the spatial perception skills: A case study. Review of International Geographical Education Online, 9(3), 618-638. https://doi.org/10.33403/rigeo.601734

Sitorus, D. S., Siswandari, \& Kristiani, K. (2019). The Effectiveness of Accounting E-module Integrated with Character Value to Improve Students' Learning Outcomes and Honesty. Cakrawala Pendidikan, 38(1), 120-129. https://doi.org/10.21831/cp.v38i1.20878

Sudjana, N., \& Ibrahim, I. (2008). Penelitian dan Penilaian Pendidikan. Sinar Baru Algesindo.

Sugandi, D. (2015). Pembelajaran Geografi sebagai Salah Satu Dasar Pembentukan Karakter Bangsa. Sosio Humanika, 8(2), 241-252.

Sugiyanto, S., Maryani, E., \& Ruhimat, M. (2017). Studi Tingkat Kepahaman Guru IPS SMP tentang Literasi Geografi. Jurnal Pendidikan Ilmu Sosial, 26(2), 205-218.

Syaichudin, M., Ardhana, I. W., Degeng, I. N. S., \& Sulton, S. (2016). Pengaruh Strategi Pembelajaran Problem Based Learning (PBL) Terhadap Pemahaman Konsep IPS Kelas Viii di Smp Dalam Self Regulated Learning. 2nd Psychology and Humanity, Seminar ASEAN. Psychology Forum UMM, 19-20 February 2016, Malang, 240-247.

Tamba, E. E. A., Mulyoto, M \& Sudiyanto, S. (2018). Pengaruh Model Pembelajaran Problem Solving Learning Dan Project Based Learning Terhadap Hasil Belajar Sejarah Ditinjau Dari Kreativitas Siswa di Sma Negeri Se-Surakarta. HISTORIKA, 21(1), 81-94.

Tesi, M. R., \& Wilujeng, I. (2017). Pengembangan Perangkat Pembelajaran Project-Based Learning untuk Membekali Foundational Knowledge dan Meningkatkan Scientific Literacy. Cakrawala Pendidikan, 36(1), 34-43. https://doi.org/10.21831/cp.v36i1.8830

Tyrrell, S. (2009). SPSS : Stats Practically Short and Simple. Sidney and Tyrrell \& Ventus Publishing ApS.

Wau, M. P. (2017). Pengaruh Model Problem Based Learning Terhadap Hasil Belajar IPS Pada Siswa Kelas IV SDI Bajawa Kecamatan Bajawa Kabupaten Ngada. Journal of Education Technology, 1(4), 239-245. https://doi.org/10.23887/jet.v1i4.12860

Wasino, W., Suharso, R., Utomo, C. B., \& Shintasiwi, F. A. (2020). Cultural Ecoliteracy of Social Science Education at Junior High School in North Java Indonesia. Journal of Social Studies Education Research, 11(4), 52 - 83.

Winch, C., \& Gingell, J. (2008). Philosophy of Education. The Key Concepts (2nd ed.). Rouledge.

Zarvianti, E. \& Sahida, D. (2020). Designing Comics By Using Problem Base Learning (PBL) to Improve Students' Creative Thinking Skills. International Journal of Social Learning, 1(1), 75-88. https://doi.org/10.47134/ijsl.v1i1.8

Yusuf, M. (2014). Metode Penelitian Kuantitatif, Kualitatif, \& Penelitian Gabungan. Prenadamedia Group.

\section{Biographical Statements}

Nur HAMID is lecturer in Department of Islamic Community Development at Universitas Islam Negeri Walisongo Semarang, Indonesia, and is the Editor-in-Chief of the International Journal of Social Learning (IJSL). He is a Ph.D Candidate in Departement of Social Studies (Geography Education) at Universitas Negeri Semarang, Indonesia. He focuses on social studies teaching, disaster education, and geography education. 
Gillian ROEHRIG is Professor Dr., Department of Curriculum and Instruction, University of Minnesota, United States. Research and teaching interests are centered on understanding how teachers translate national and state standards into their classrooms. Of particular interest is how teachers, from preservice through induction and into the in-service years, implement inquiry-based teaching and how different induction and professional development programs can influence teachers' knowledge, beliefs, and classroom practices.

Dewi Liesnoor SETYOWATI is Professor Dr., Department of Geography at Universitas Negeri Semarang, Indonesia. She focuses on social studies and geography education

Huriah RACHMAH is a lecturer in the Department of Early Childhood Education at Universitas Islam Bandung, Indonesia. She is a Ph.D in the Department of Social Studies and focuses on teaching social studies, social skills and accounting education. Become a consultant at the Ministry of Education and Culture, as well as Bank Indonesia. Writing a reference book on teacher professional development and social skills.

Muh. Arif ROYYANI is lecturer in Department of Astronomy at Universitas Islam Negeri Walisongo Semarang, Indonesia, and is the Editorial Board of the Edutrained Journal. He is a Ph.D in Astronomi at Universitas Islam Negeri Walisongo Semarang, Indonesia. He focuses on Astronomi.

Hanifah MAHAT is Associate Professor Dr., Department of Geography and Environment, Universiti Pendidikan Sultan Idris, Malaysia. She focuses on geography environment and geography education. 